\title{
Flexibiliteit en zekerheid: een (on)mogelijke twee-eenheid?
}

\author{
Kees Vos en Nicolette van Gestel*
}

\begin{abstract}
Vraagstukken rond flexibiliteit en zekerheid domineren momenteel het debat in en over de arbeidsverhoudingen. Begrippen als flexicurity en employability staan nationaal en internationaal hoog op de sociaal-politieke agenda. Rond deze begrippen ontstaan vaak verhitte discussies, vanuit opvattingen en aannames over de positieve of kwalijke gevolgen voor werkgevers en werknemers. In dit themanummer maken we ruimte voor onderzoek naar de praktijk: slagen werkgevers en werknemers er in op verschillende niveaus (Europees, nationaal, in sectoren en ondernemingen) om hun wensen en interpretaties van flexibiliteit en zekerheid te combineren en te realiseren? Met andere woorden: is de combinatie van flexibiliteit en zekerheid een utopie of kan er wel degelijk synergie ontstaan, zoals het begrip 'flexicurity' suggereert? Deze vraag stond onlangs centraal op het lustrumcongres van de Nederlandse Vereniging voor Arbeidsverhoudingen (NVA) op 26 september 2008 onder de titel 'Flexibiliteit en zekerheid: Hoe organiseer je dat in de praktijk?'. Met dit congres is het 40 -jarig bestaan van de NVA in het Haagse SER-gebouw onder ruime belangstelling gevierd. Een blik op de inhoudsopgave van recente afleveringen van het Tijdschrift voor Arbeidsvraagstukken laat zien dat ook in het onderzoek deze thema's veelvuldig aan de orde zijn. Vandaar dit themanummer als een joint venture van NVA en het Tijdschrift voor Arbeidsvraagstukken. Een aantal bijdragen aan het lustrumcongres is hierin verder uitgewerkt en aangevuld met andere artikelen en columns.
\end{abstract}

\section{Naar een nieuwe balans tussen flexibiliteit en zekerheid}

De geschiedenis van de arbeidsverhoudingen laat zich lezen als de ontwikkelingsgang van (vrijwel) volledige flexibiliteit naar een zo groot mogelijke (sociale) zekerheid. Sociale stelsels, 'modellen' als het Angelsaksische, Rijnlandse, Scandinavische, zélfs het Europese, zijn de neerslag van consensus over de mate waarin een balans op dit punt maatschappelijk aanvaardbaar en economisch werkbaar wordt geacht (Esping-Andersen, 1990). Die op een gegeven moment bestaande consensus sluit afwijkende opvattingen uiteraard niet uit. Over elk model wordt met zekere regelmaat betoogd dat de balans te veel naar de ene of naar de andere kant is doorgeslagen (Scharpf, 2000). Niet zelden wordt de behoefte geuit om de ontwikkelingsgang in omgekeerde richting af te leggen. Een organisatie als de OECD heeft een dergelijke boodschap voortdurend als wenkend en werkend perspectief uitgedragen.

Achteraf bezien markeren de enkele decennia geleden ingezette processen van deregulering en decentralisering de eerste schreden op de weg naar verandering. Hiermee ontstaat immers ruimte voor de in de jaren tachtig opkomende flexibiliseringgolf. Globalisering, internationalisering van het bedrijfsleven en een snelle toename van de concurrentiedruk bevorderen de behoefte aan flexibiliteit van werkgevers, ook wanneer het de arbeidsverhoudingen betreft. Daarnaast refereren ook werknemers in toene-

* Kees Vos is voorzitter van de redactie van het Tijdschrift voor Arbeidsvraagstukken.

Nicolette van Gestel is universitair hoofddocent aan de Radboud Universiteit Nijmegen en gastredacteur van dit themanummer. 
mende mate aan flexibiliteit, ten gunste van een betere work-life-balans in aansluiting op verschillende levensloopfasen. Op dit moment is vooral de grote mate van consensus over de wenselijkheid van een balansvernieuwing tussen flexibiliteit en zekerheid opmerkelijk. Vooral omdat er over de combinatie(s) van flexibiliteit en zekerheid nog zoveel verschil van mening bestaat, ook al suggereert het gebruik van de term 'flexicurity' zoiets als een harmonische twee-eenheid.

\section{Een groeiende flexibiliteit in de arbeidsverhoudingen}

Aanvankelijk staat tegenover de toenemende behoefte van bedrijven aan flexibilisering van arbeidsorganisatie en personeelsbestand, van arbeidstijd en arbeidsvoorwaarden, niet veel meer dan de hoop op meer werkgelegenheid. En ook dan is het perspectief toch vooral dat minder werkloosheid de kans biedt de verzorgingsstaat te behouden door haar te verkleinen. De in 2000 geformuleerde Lissabon-strategie zorgt hier voor de politieke legitimering: economische groei, meer concurrentievermogen en modernisering van het Europese sociale model moeten zorgen voor meer en betere werkgelegenheid. Met het roemruchte Akkoord van Wassenaar van 1982 als startpunt van de werkloosheidsbestrijding via loonmatiging en korter werken kan ons land in veel opzichten model gestaan hebben voor de Europese therapie. Sindsdien is loonstijging in Nederland geen automatisme meer, ook al omdat de automatische prijscompensatie geleidelijk uit vrijwel alle cao's is verdwenen. Daar staat tegenover dat variabel, resultaatgericht belonen steeds vaker vast onderdeel van de cao-afspraken is, zodat - overeenkomstig de aanbeveling van de Stichting van de Arbeid in 2007 - de lonen kunnen 'mee-ademen met de conjunctuur'. Binnen 20 jaar na Wassenaar heeft een groot aantal Europese landen de receptuur van een gematigde loonontwikkeling overgenomen, al dan niet in combinatie met flexibele beloningsvormen.

De flexibiliseringsbehoefte van bedrijven heeft verder tot resultaat gehad dat overal in Europa de arbeidstijden zijn geflexibiliseerd en vormen van tijdelijk en/of deeltijdwerk zijn toegenomen. Vanwege de omvang van het deeltijdwerk geldt ons land hier in veel opzichten als gidsland, terwijl bedrijven in landen als Finland, Portugal en Tsjechië in hoge mate gebruikmaken van tijdelijke contracten (European Foundation, 2008). In totaal werkt circa $30 \%$ van de werknemers in de 25 lidstaten van de EU via tijdelijk dan wel deeltijdwerk (EC, 2006). Daarmee lijkt het traditionele patroon van een vaste voltijdse werkkring steeds meer achterhaald te worden.

\section{Werknemersperspectieven}

Op het eerste gezicht is flexibiliteit niet strijdig met de wensen en verwachtingen aan werknemerskant. In de loop van de jaren negentig gaan ook zij op zoek gaan naar een nieuw evenwicht: waar ligt de in een levensloop acceptabele balans tussen leven en werken? Die behoefte aan flexibiliteit manifesteert zich vooral in de massale toepassing van flexibele arbeidstijden, van zorgverlof en van vormen van vervroegde of gefaseerde uittreding. Anders ligt het zodra de (baan)zekerheid in het geding is. Dat bewijst niet alleen de hoogoplopende discussie over het ontslagrecht. Ook is er kritiek op sommige effecten van toenemende flexibiliteit zoals verslechtering van de positie van (groepen) werknemers op de arbeidsmarkt. In de visie van de Europese vakbeweging heeft de flexibilisering in de zin van deregulering vooral geleid tot erosie van werknemersbe- 
scherming, waardoor groeiende aantallen werknemers in een kwetsbare positie terecht zijn gekomen. Om dergelijke negatieve beeldvorming weg te nemen komt de Europese Commissie in 2005 met een hernieuwde lancering van de Lissabon-strategie, waarin flexicurity - inclusief een rol voor de sociale partners bij de realisering daarvan - nog eens extra is aangezet. De ambitie is om, in de woorden van een Europese expertgroep, het beste van twee werelden te combineren: de economische dynamiek en flexibiliteit van de 'nieuwe' (USA) wereld met de zekerheid en de bescherming van de 'oude' (Europese) wereld (Expert Group on Flexicurity, 2007). De verwachting is dat via de beschikbaarheid van contractuele regelingen, een actieve arbeidsmarktpolitiek, geloofwaardige stelsels van leven-lang-leren en gemoderniseerde stelsels van sociale zekerheid een aanvaardbare balans tussen flexibiliteit en zekerheid bereikt kan worden (EC, 2007). Conform de aanpak van de Open Methode van Coördinatie (OMC) is de realisering daarvan vervolgens de taak van de Europese lidstaten.

\section{Het beste van twee werelden?}

Een ambitie als hier verwoord zal in algemene zin nauwelijks weerstand oproepen. Wie zal bezwaar willen maken tegen een combinatie van het beste van twee werelden? Niettemin stuiten beleidsvoornemens op dit gebied regelmatig op de nodige scepsis, zeker bij de sociale partners en zeker ook wanneer gepoogd wordt het evenwicht tussen flexibiliteit en zekerheid nader te concretiseren. Uit longitudinaal onderzoek komt naar voren dat in vele opzichten de verschillen in sociale modellen binnen de Europese Unie groter zijn dan tussen Europa en de USA (Alber, 2006). Zoals Sonja Bekker en Ton Wilthagen in hun bijdrage aan dit themanummer aangeven heeft er (ook) nogal wat water door de zee moeten vloeien alvorens een (meer) gemeenschappelijke visie van de sociale partners op Europees niveau tot stand is gekomen. En consensus over de wenselijkheid van een nieuw evenwicht wil nog lang niet zeggen dat binnen landen, sectoren en bedrijven overeenstemming over de concrete invulling bestaat. In de $\mathrm{Ne}$ derlandse arbeidsverhoudingen maakt flexibilisering van de arbeid via bijvoorbeeld cao à la carte of levensloopregeling al geruime tijd deel uit van het standaardpakket arbeidsvoorwaarden, ook al gaat het daarbij zoals Joop Schippers in zijn column aangeeft nog maar om wat 'gerommel in de marge'. Toch is blijkens de CBS-data in de bijdrage van Martijn Souren het aandeel flexwerkers in ons land sinds 2004 voortdurend gestegen. Wanneer het gaat om de verdergaande flexibilisering van het personeelsbestand, in casu verruiming van de ontslagbescherming, is - zoals ook Ton Wilthagen in zijn column onderstreept - consensus echter ver te zoeken. Nationale tradities op het gebied van sociaal beleid spelen een belangrijke rol, met name ook wanneer het, zoals Martijn van Velzen aangeeft, gaat om de praktische toepassing in Deense en Nederlandse ondernemingen. Volgens Frank Tros hebben vergelijkbare beleidsveranderingen op nationaal niveau ten aanzien van oudere werknemers een verschillende uitwerking op bedrijfsniveau. Uit de bijdrage van Trudie Schils en Paul de Beer blijkt dat in de onderzochte landen vergelijkbare combinaties van flexicurity tot uiteenlopende arbeidsmarktprestaties en uiteenlopende combinaties tot vergelijkbare arbeidsmarktprestaties kunnen leiden.

Daarmee is op dit moment de organisatie op praktijkniveau (en dus ook de door NVA aangesneden thematiek) van niet te onderschatten belang. Dit niet alleen omdat deregulering en decentralisering de ruimte voor uiteenlopende initiatieven op bedrijfsniveau bieden, maar ook omdat op meso- en micro-niveau een eventuele onbalans zich vaak 
met nadruk manifesteert. Ten aanzien van de balans tussen werk en privé signaleren Peters, Den Dulk en Van der Lippe in hun bijdrage positieve maar ook negatieve effecten. Het opleidingsniveau blijkt daarbij een factor van betekenis te zijn: blijkens de bijdrage van De Jong, Wiezer en Joling over de effecten van flexibele contracten op welzijn en gezondheid blijkt de baanonzekerheid vooral voor lager opgeleiden negatieve gevolgen voor de werknemers te hebben. Dit verwijst naar het belang van employability, de mate waarin werknemers zijn of worden toegerust om tijdens hun levensloop de naar verwachting frequente transities op de arbeidsmarkt succesvol te volbrengen. Op basis van verkennend onderzoek suggereren Goudswaard, Brugman en De Leede dat dergelijke toerusting ook mogelijk is voor uitzendwerkers. Doorgaans blijkt evenwel de employability juist het kleinst te zijn bij degenen die dit het meest nodig hebben. Het is daarom een open vraag of de vervanging van baanzekerheid door werkzekerheid bijdraagt tot een maatschappelijk aanvaardbare vorm van balansvernieuwing.

Over de wenselijkheid van balansvernieuwing mag dan consensus hebben bestaan, over de daadwerkelijke vormgeving daarvan zijn en blijven de meningen verdeeld. Dit temeer nu de kredietcrisis het vertrouwen in de economische dynamiek van het Angelsaksische model danig heeft ondergraven. Zodoende blijven de arbeidsverhoudingen ook in de toekomst een boeiend thema voor onderzoek en discussie. Hopelijk biedt dit een-tweetje van NVA en TvA daarvoor een attractieve aanzet.

\section{Literatuur}

Alber, J. (2006). The European Social Model and the United States. European Union Politics, 7(3): 393-419.

Esping-Andersen, G. (1990). The Three Worlds of Welfare Capitalism. Cambridge: Polity Press. European Commission (2007). Employment in Europe 2005: Recent Trends and Prospects. Brussel. European Commission (2006). Industrial Relations in Europe 2006. Luxembourg: Publications Office.

European Foundation (2008). Flexibility and security over the life course, eds. R. Muffels, H. Chung, D. Fouarge, U. Klammer, R. Luijkx, A. Manzoni, A. Thiel \& T. Wilthagen. Luxembourg: Publications Office.

Expert Group on Flexicurity, Flexicurity Pathways. Interim report from the rapporteur T. Wilthagen presented at the Stakeholder Conference on Flexicurity, Brussels 20 April 2007, p. 9.

Scharpf, F. (2000). The Viability of Advanced Welfare States in the International Economy: Vulnerabilities and Options. Journal of European Policy, 7 (2): 190-228; Esping-Andersen, G., Gallie, D., Hemerijck, A. \& Myles, J. (eds.) (2002). Why We Need a New Welfare State. New York: Oxford University Press. 